\title{
Study of the Accounting Policy Choice Mechanism in Chinese Listed Companies
}

\author{
Dongsheng Tang \\ Accounting and Trade Department, Chongqing City Management College, Chongqing, China \\ Dongsheng_Tang@yeah.net
}

Keywords: Accounting policy; Accounting policy choice; Listed Company

\begin{abstract}
In this paper, with the basic concept of accounting policies, combined with the theory of accounting policy choice, the choice of accounting policies is specified in the inevitability of the existence objective and subjective needs, but it is also subject to certain accounting policy choices facing business in the accounting environment. Contacting the actual situation of the accounting policy choice of China's listed companies, this paper has been used the standardized methods, analyzed many problems and its reasons on accounting policy of the listed companies in China. It has been analyzed the results and found a feasible way to solve the problem.
\end{abstract}

\section{Introduction}

Since the era of planned economy enterprises are mainly in accordance with the provisions of financial and related systems for asset valuation and revenue recognition, there is no choice of accounting policies. Therefore, there are few studies of accounting policy choice. Until the beginning of the last century in 90s, companies have the right on the independent choice of accounting policies. China's enterprises began to study the issue of accounting policy choice, but they also had the introduction of foreign research results: Yuan zhi ECT. [1] Proposed that it can only be the complex accounting policies position, depending on the accounting, staff and the owner's position in the enterprise. Li duansheng supposed [2] that corporate the accounting policy choice position is correct thinking. Xie deren viewed [3] that the only possible goal of accounting is procedural rationality. Modern enterprise system and the principal-agent contract determine the position of enterprises to choose the accounting policies. And various stakeholders are the contract between the companies accounting policy choice that should be considered as an important factor. Tang songhua [4] discussed the impact of accounting policy choice factors, position and other business owners have their choice of accounting policies that are reasonable and inevitable: Firstly, the governance structure should be met the perfect multi-stakeholder needs; Secondly, the accounting standards are not standardized; thirdly, the accounting information is not the perfectly competitive market. Corporate management should be considered in the selection of accounting policies with the contractual relationship between the stakeholders. In particular, consideration should be given to shareholders, creditors and the government's contractual relationship.

In addition, some scholars have advocated the considerable empirical research and focused on the securities market information control. Taken the "Enterprise Accounting Standards" as the starting point, Zhang weiguo ECT. [5] Considered the development of China's security market, accounting policies and other factors of the urgent need to explore the necessity of empirical accounting research, possibility, the nature and characteristics. Wei gang [6] had studied the remuneration of senior management and operated the performance of listed companies, finding no significant between the correlations. Jiang yihong, etc. [7] had investigated the listed cause changes in the accounting policy, which had analyzed the motives and manipulation of accounting change in accounting policy that is not standardized. Cui xuegang ect. [8] had use the rising and falling of Huatai Insurance case of accounting policy choice on China's economic consequences, analyzed the process of production and the economic consequences of the accounting policies derived the basic law. 
The accounting policy choice on few empirical studies had been mainly tested the three assumptions of the economic consequences of accounting policy choice, and earnings management. There are still many issues to be further research. In this paper, it has combined with the accounting policy choice of the listed companies, taken the advantage of other people's research results and the use of standardized research methods through the logical reasoning. It has discussed the accounting policy choice of the listed companies and the reasons for the problems in detail - optimized selection of accounting policies listed a number of recommendations to the guidelines. The system of development agencies has provided some reference to China's capital market, which has standardized and improved our quality of accounting information of the listed companies.

\section{The basic theory of the listed accounting policy choice}

\section{Agency theory}

Agency theory is the agency relationship based on the contractual relationship of the existence, which has entrusted with the fiduciary relationship between the two sides to sign a contract agency. The principal has authorized the trustee certain rights that Dai Liren had the interest of the principal agent to complete their fiduciary responsibilities. The agent is the authorized agent for some principal decision-making power of the interests and the agents of certain activities that were engaged in a contractual relationship. As the modern business enterprise system, the separation of management, ownership and agency relations have naturally produced.

China's company Law has expressly provided that the share of the company is the only listed company in China had taken the form that is not to take other forms. The most important features are the separation of the ownership and management rights and the stock company system. The owners and the shareholders are not directly involved in the business management. The business owner only has control in the distribution of the final distribution of property rights to bear the greatest risk of enterprises as the bearer business of the ultimate risk. By the board of directors, managers and other components of the management staff of enterprises with the right management, the company management must have to pay labor remuneration, that is, those who pay the ultimate shareholders and they create the principal-agent relationship. Business operators and the agency between the shareholders have directly affected the choice of accounting policies that affects the distribution of benefits.

\section{Property Theory}

The research focuses on the property rights theory of contractual relation. They believe that the contract between the rights and obligations shall not complete, which isn't included in the contract or the part of the contract rights that should be vested in the owner of the assets, and the shareholders have the residual claims. From the perspective of this, the contract reflects the most efficient control of the asset that should be attributed to. In other words, the allocation of property rights is extremely important. In addition, the structure theory of the corporate capital incompletes the contract basis. The development of the theory scholars and entrepreneurs are lack of capital. Its management rights can participate in the transaction management and investors invest in the ownership of assets but do not participate in the management business. Its long-term contract is not entirely, and it is seen as the "vertical integration". Thus, it can create two different interests on the pursuit of fame and income entrepreneurs. The investors have concerned about the profit maximization with the purpose of the two sides in conflict; if the contract in the first can't be clarification of rights and obligations, then the distribution of corporate control is critical.

\section{Stakeholder Theory}

Many enterprises are the combination of contractual relation by signing a wide range of contract or contract specified in the contract the rights and obligations of stakeholders. It means not just the shareholders, creditors, management, including the government and the potential investors and so on. The two sides have signed the contract or the contract is equal and independent status of the subject, which is relative to the corporate governance that also requires the equal and independent features. What we call the main stakeholders includes the business interests of all that can affect the person or 
organization, or all can be affected by the economic behavior of enterprises to the person or organization.

\section{The asymmetric information theory}

Reciprocal information has unevenly distributed among individuals, which was more than one other available information. It is the information asymmetry. In the product market, buyers and sellers are different in the information on the products, the seller usually master more information with the two elements of the information asymmetry between the parties. Principal-agent relations are in the modern enterprise system. Due to the separation of ownership and management, owners and managers understand the extent of information asymmetry. The information managers have significantly been more than the owner to better understand the operation of enterprises. Thus, it is compared with the owners of its dominant position information.

\section{The main problems and causes of the accounting policy choice in public company}

\section{The main problems on the public company accounting policy choice}

Use of earnings management choice for accounting policy .The appropriate accounting policy choice has many advantages, it not only can reduce the agency cost, but it can also improve the efficiency of enterprises. The accounting policies of listed companies can make the choices, with the opportunistic tendencies, it is mainly as follows: In order to prevent the government for the supervision and management departments, they can reduce the tax burden and control the market price of the stock. The purposes do not contain the conception of accounting policy choice; and even some companies use special provision for impairment of assets and reversal of timing differences, the different accounting periods are for the income adjustment. The benefits of this rule make a lot of companies interested in this, which is familiar with the amount of the financial technology company. Its accounting policy choice of services is in earning management. This type of opportunistic accounting policy choices is really made of individual managers and other stakeholders. The authorities have realized the maximum benefits, but they also reduced the interest of other stakeholders from the company's long-term development perspective, which can't simply make the capital market allocation of social resources.

The poor operability for the accounting policy choice : Accounting theory can guide the accounting practice as a specific process, but it is also the basis for the determining system of accounting policies. The appropriate advance is a major feature of accounting theory, which can explain the accounting practices with the better predict future trend. Our provision impairment of entrusted loans and income tax accounting method on the provisions can fully reflect the predictability of accounting standards. Listed companies in China are commissioned by the form of small loans. Most of them have adopted the tax payable method, which are different from the foreign tax to effect accounting method. Therefore, the provisions of these accounting policies have large forward-looking, showing the poor practical feasibility.

\section{The analysis for the cause's problems on the accounting of the listed companies}

The corporate governance structure is not perfect: Compared with the western countries, China's listed companies have the characteristics of high concentration of equity. Seventy percent of the outstanding shares held by the state and legal persons, and only30\% of the outstanding shares are by the major shareholders, officers or government appointed management. Therefore, the company is mostly the internal control, for the benefit of services; the management inefficiency can't guarantee the interests of outside investors. The listed companies in China haven't yet established the effective incentive mechanism; management compensation and operating results failed to linked the main short-term rather than the long-term incentive compensation, which causes the pursuit of the short-term benefits that may damage the company's long-term development. The unsound management of corporate governance structure provides the opportunity to achieve the personal interests, namely, the use of improper accounting policy choice for earnings management.

The ability of poor accounting personnel practice : With the promulgation of the new accounting standard and accounting system, the enterprise has the right of the accounting policy choice with 
more and more space, but the majority of our managers and accounting personnel are lack of awareness of the accounting policy choice. Some companies have failed the scientific and rational choice of accounting policy. The accounting staff of professional quality is to choose the reasonable as one of the important accounting policies affecting factors. As the rapid economic development, it has changed the accounting environment. The new business is emerging innovation, which increases the variety on the development of the accounting profession to determine the degree. It is difficulty, and the poor professional quality of the accounting staff can't meet the real needs. The leading companies have chosen the unreasonable accounting policy and accounting staff to give up some better accounting for the business the right policies, which has the pursuit of the simple operation. So that, the rights are conferred by the mere formality criteria.

The non-standard practice of the CPA profession: CPA audit of the listed companies have chosen and changed in accounting policy, which can play a role in the supervision and restraint. As the imperfections of the external audit in the practice environment, in the course of their practice, the CPA's independence, objectivity and impartiality are difficult to maintain, which can affect the CPA's audit quality.

\section{The improvement of the recommendations for the public company accounting policy}

\section{The specification principle of the choice on the public company accounting policy}

Accounting policy choice is various interest groups; it can mediate the various stakeholders in the economic relations of the distribution, which can ease the contradiction of the interests. But it is also the process of redistribution in corporate wealth rather than simply being corporate accounting problem. The accounting policy choice is a complex process. Throughout the whole process of the enterprise, it includes the enterprise financial operations, the initial recognition, measurement and subsequent accounting treatment process. It has selected the appropriate accounting policies that are conducive to the realization of enterprise value maximization. Therefore, enterprises should follow the certain principles, which are based on the full consideration of various factors, choosing the most appropriate accounting policies of enterprises.

\section{Corporate Governance}

To ensure the selection of the appropriate accounting policies, they can ensure that all the interest groups should be assigned to share. We must improve the company operations, management efficiency of the Company's shareholders, the board of directors and management such as organizational structure, its governance and oversight role. Accounting policy choice is for the reality of the situation and the current effects of the company's current management, we should solve the following problem:

(a) The clearly property rights will help standardize the financial information

(b) To strengthen the oversight role of independent directors

(c) The establishment of compensation and performance incentives

(d) To develop the strategic partnership

(e) To further improve the disclosure system of the company's financial information

\section{To increase the level of accounting personnel practice}

Professional level accounting staff directly affected their choice of accounting policies, in order to select appropriate and reasonable corporate accounting policies rely on high professional level accounting staff. Only by improving the overall professional quality of the accounting profession, in order to improve the quality of corporate financial information. Enterprises should strengthen in-service training of accounting personnel, regular or irregular basis to finance staff training, new knowledge; only the employment of induction financial officer qualification certificate, professional and ethical standards for those with low financial officers are determined not to employ, and require the Finance personnel in strict accordance with the provisions of operation, firing those who do not operate according to the provisions of the accounting staff. 


\section{To strengthen the external audit}

CPA audit is an external monitor; you can provide the reasonable assurance that the reliability is the financial information. But, it can also play monitoring companies that have chosen the reasonableness of accounting policies and enhance the users' financial statements. It can provide the information on the financial statements level of trust and make the right investment decisions. Therefore, improving the quality of auditing opinions, the information for the users' financial statements is essential to make sensible choices. We need to strengthen the role of the audit and supervision of accounting. The CPA profession can improve the overall professionalism and ethical standards. The audit of listed companies is the independently certified public accountants audit clients. It can't let the customers have the financial interest, or its objective impact and fair principles.

\section{Conclusion}

With the analysis of the problems of listed companies for the public company accounting policy choice, it has proposed recommendations for the main issues of the accounting policy choice from the choice of accounting policies, which can the improve corporate governance structure, the professional level accounting personnel and the external audit and so on. Moreover, in addition to irregularities punishment, China should attach importance to the moral aspects of the construction industry and carry out the CPA educational activities with honest and trustworthy. Even activities will be spread over the whole education, especially for the senior management of listed companies. When the integrity of education and accounting personnel are acting in good faith in the whole society, China's CPA industry will be greatly developed.

\section{References}

[1] ZHAO Jian;Personal view about deepening the inquiry into theory of labor value[J];Journal of Anhui Normal University(Philosophy \& Social Sciences);2002-06

[2] CHEN Chao;Study on Profit Management in Agricultural Listed Company[J];Journal of Anhui Agricultural Sciences;2007-06

[3] WU Wei,XIANG;The countermeasure analysis on the management of distorted accounting information[J];Journal of Anhui Electrical Engineering Professional Technique College;2006-02

[4] XIA Ju-ziAnalysis on the Present Situation and Causes of the Accounting Risk in China's Enterprises[J];Journal of Anhui Business College of Vocational Technology;2006-04

[5] Jin Koujuan;Principle of Good Credibility and Distorted Accounting Information From a Legal Viewpoint[J];Journal of North China University of Technology;2002-04

[6] WU Long;An Analysis of Other Causes of False Accounting and Its Countermeasures[J];Journal of Beihua University;2004-02

[7] ZHANG Xiu-mei;On the Relationship between Resources Diverted Away from Listed Companies by Related Parties and Earnings Management or Controlling Right of the Biggest Stockholder[J];Journal of Beijing Institute of Technology(Social Sciences Edition);2008-04

[8] HUANG Jin-zhi,;On Management Auditing to Compensate Investors' Expectation Gap[J];Commercial Research;2004-23

[9] ZHANG Qian;On Accounting Integrity and the System of Property Right[J];;2004-05

[10] Jin Yuhong;Strengthening credit supervision over financial industry Perfecting personal credit system[J];Journal of Changchun Finance College;2003-0 